\title{
The innovative 3D printer head. Part 1. Concept
}

\author{
Innowacyjna głowica do podawania materiału w drukarkach \\ przyrostowych. Cz. 1. Koncepcja
}

\section{ANNA RĘBOSZ-KURDEK WACŁAW GIERULSKI ARTUR SZMIDT *}

\begin{abstract}
The article presents the concept of 3D printer head equipped with a mixing system and a gas shield system. The solution has the protection of intellectual property rights in the form of application of the invention in the Polish Patent Office. Currently used solutions and innovativeness of the head according to the invention were discussed. Constructional solutions of individual components of the head including a description of their operation were presented. The concept is the basis for research on the construction of a prototype of this head and verification of the effectiveness of its operation and functionality in laboratory conditions.

KEYWORDS: 3D print, printer head, mixing system, gas shield system, construction industry
\end{abstract}

3D printing (spatial printing) is the process by which physical objects are created on the basis of a digital model by layering materials. The first official 3D printing method stereolithography (SLA) - was patented in 1986 by 3D Systems, the founder of which was Charles Hull [2]. Over the last decades, 3D printing has become one of the fastestevolving technologies. In the initial period of development it was expensive and reserved for professional use. Only large industrial companies or research centers used it. With the passage of time, 3D printing has become much cheaper and more accessible to a wide range of individual users. In 2006, the first prototype spatial printer model for home use [3] was presented, which resulted in the emergence of more and more entities producing inexpensive 3D printers on the market. Thanks to constant development, the technology of spatial printing is more and more advanced and finds new areas of application - from the production of everyday objects $[4,5]$ and prototypes [6] to final products for the aviation industry $[4,7,8]$, automotive $[4,9]$ or medical $[10,11]$. 3D printing technology also enters the construction industry, where it is used both at the stage of creating an architectural design and implementation of the object [12]. 3D printing is becoming an indispensable tool in the work of architects, enabling appropriate presentation of projects to potentia clients.

\footnotetext{
* Dr inż. Anna Rębosz-Kurdek (arebosz@tu.kielce.pl); dr hab. inż. Wacław Gierulski, prof. PŚk (gierulsk@tu.kielce.pl) - Katedra Inżynierii Produkcji Politechniki Świętokrzyskiej; dr inż. Artur Szmidt (szmidt@tu. kielce.pl) - Laboratorium Prototypowania Politechniki Świętokrzyskiej
}

On a 3D printer you can quickly and cheaply prepare a physical model of the facility in a suitable scale and in accordance with the technical documentation (with precise reproduction of all details).

This technology is also useful in the construction phase when creating monolithic structures directly on the construction site [13] and prefabricated elements in the production hall, which are then transported to the construction site in a ready-to-assemble form [14].

The use of $3 \mathrm{D}$ printers in this area can significantly improve the investment process by shortening the time of building execution, and this translates into lower costs. In addition, this method produces less waste and dust in the construction process compared to traditional methods. This is an extremely important aspect, because in today's innovative building industry the emphasis is on the development of solutions favoring the protection of the environment.

Regardless of the printing method or area of its application, every 3D printing process requires three key elements: hardware, materials and software. Therefore, scientific and research work is being carried out in the area of developing new or improving existing devices $[15,16]$ and materials [17,18], which will help to improve the printing process.

This article presents the model of an innovative head for material feeding in incremental printers, equipped with a system allowing mixing of two components (liquid building material and liquid additive improving the properties of the material forming the printout) and a gas shielding system.

\section{D printing in construction - examples of achievements}

Among the 3D printing technologies in the construction industry, Contour Crafting technology, developed by a team of scientists from the University of Southern California, is most often used [19]. It consists in fast application of successive layers of concrete mix through a huge printer until large elements are obtained.

The design of the printer is based on the crane, slightly wider than the erected building, on which the computercontrolled arm with the mounted head moves (fig. 1). The device pours the concrete mass using a nozzle, and the individual layers are applied to each other in accordance with a computer pattern. 


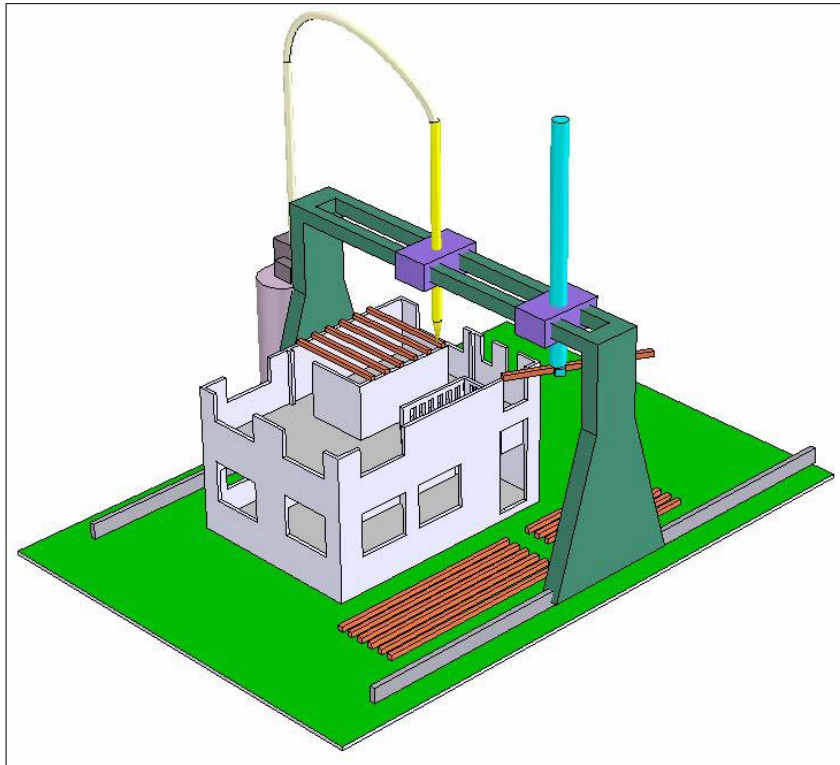

Fig. 1. 3D printer diagram used in Contour Crafting technology [19]

The walls are a light structure, which has a zigzag shape inside (fig. 2). The free spaces between the contours of the wall are a place to fill with thermal insulation. In this way, the building is unfinished, ready for further finishing.

Contour Crafting technology is used, among others by the Chinese company WinSun, which excels in building 3D printing applications. The 3D printer constructed by the company imposes successive layers of a concrete mix, created from various types of industrial and construction waste - this is how individual prefabricates are manufactured, which are then transported and assembled directly at the construction site.

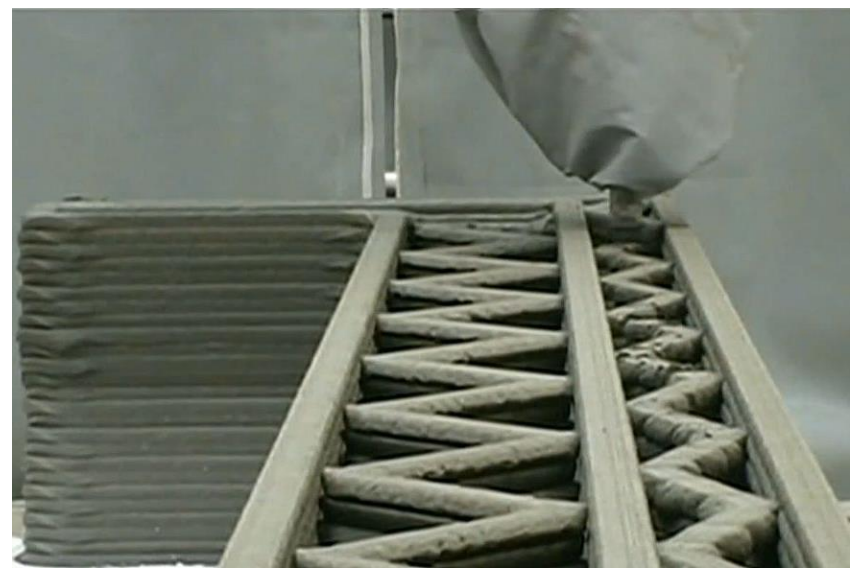

Fig. 2. Walls created in Contour Crafting technology [14]

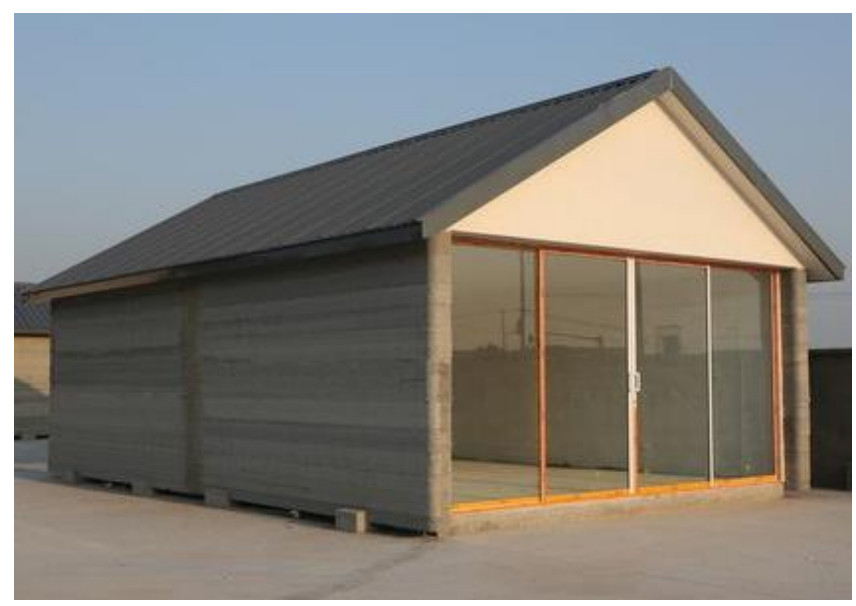

Fig. 3. Single-story building made by WinSun in 3D printing technology [20]
Appropriate stability and strength of the structure is ensured by steel reinforcement made with traditional methods. In 2014, the company made 10 single-story, freestanding buildings within a day, which are located in a technology park in Shanghai, where they serve as office spaces (fig. 3). A year later, in the Suzhou Industrial Park, the company presented two multi-story buildings (fig. 4). They had a demonstrative character, showing the possibilities of using $3 \mathrm{D}$ printing in the construction industry.

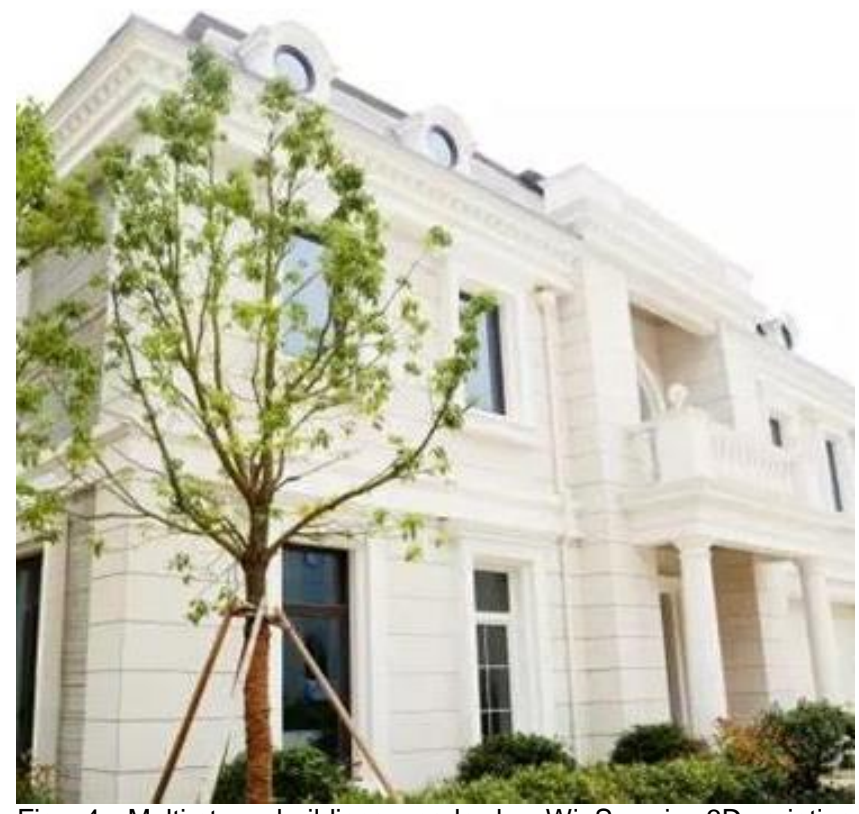

Fig. 4. Multi-story buildings made by WinSun in 3D printing technology [21]

In 2017, the American company Apis Cor presented the first residential house with an area of $38 \mathrm{~m}^{2}$, which was created in just 24 hours in Stupin near Moscow (fig. 5). It was made directly on the construction site using a mobile printer. The building has a non-standard shape - in this way, the creators emphasized that $3 \mathrm{D}$ printers can be used to create unique objects with unusual geometry.

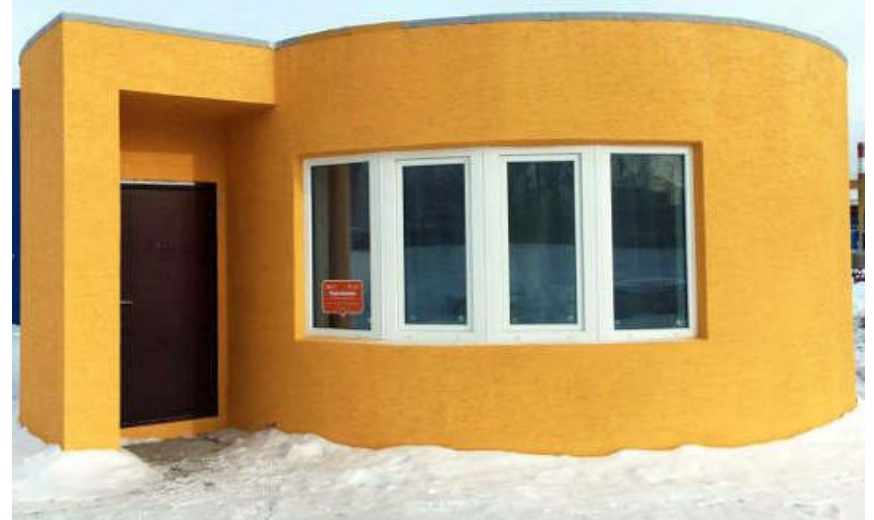

Fig. 5. House made according to the design of Apis Cor in 3D printing technology [13]

In April 2018, a house built according to the patented 3D printing method called BatiPrint 3D, developed by scientists from the University of Nantes, was presented in the French town of Nantes (fig. 6a). This facility, like the building of Apis Cor, was built directly on the construction site, but has a larger area $-95 \mathrm{~m}^{2}$. Using a mobile printer, the frame was made of polyurethane foam within 18 days and then the empty spaces were filled with concrete (fig. 6b). Frames for windows and entrance doors were inserted during the creation of the basic structure. 


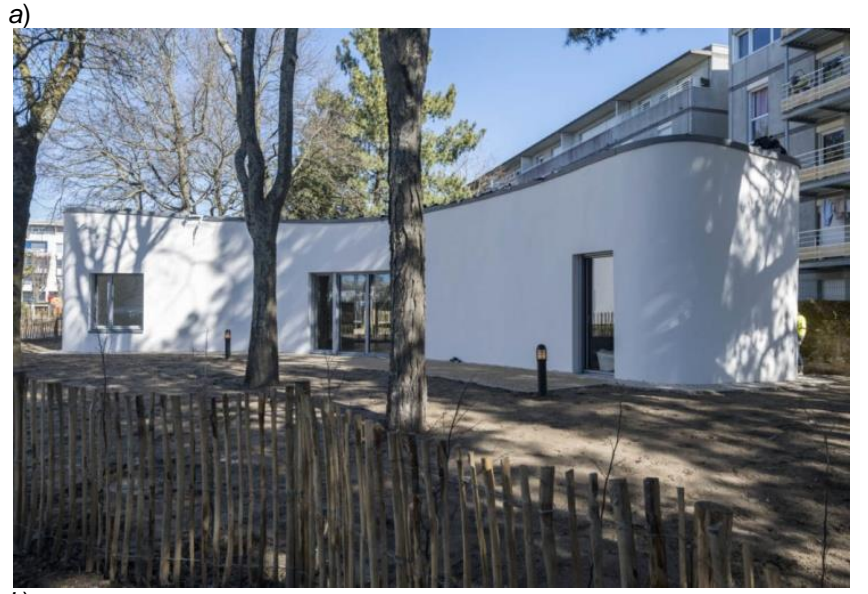

b)

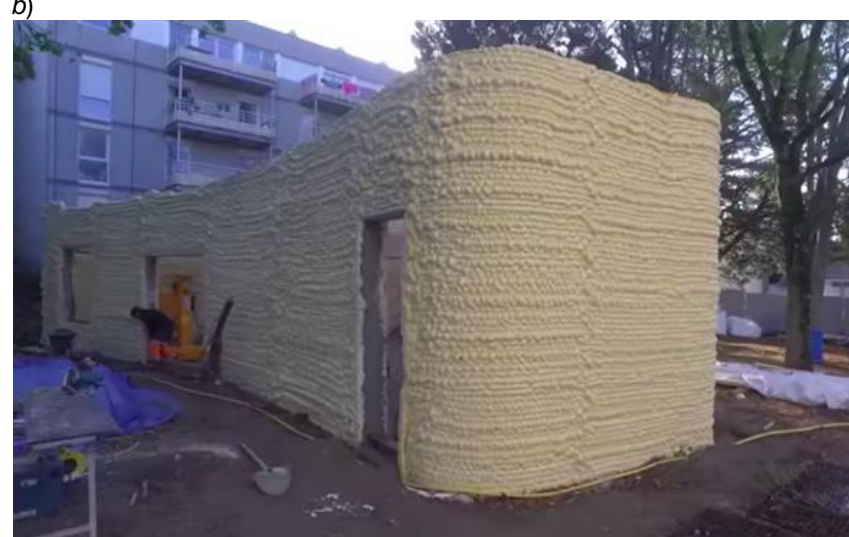

Fig. 6. House made according to the project of scientists from the University of Nantes in 3D printing technology: a) finished building, b) skeleton of walls [22]

\section{Concept of an innovative head}

- Innovation of the solution. The biggest challenges in the application of 3D printing technology in construction are both the design of the printer and the development of a building mix that must meet specific requirements. Currently, intensive work is being carried out to find a material with adequate strength properties and sufficiently fluid consistency that can be easily extruded from the print head, and at the same time it will cure quickly enough to allow the next layer to be applied.

Known constructions of heads allow for delivery of only a homogeneous material - when the building material is a mixture of several components, its preparation takes place earlier outside the head. The problem arises when one of the components of the mixture accelerates the mass binding process. Earlier mixing of ingredients may lead to a situation where the curing starts before leaving the head, which will make it impossible to print or deteriorate its quality.

The solution presented in this article is a head with a builtin system allowing the mixing of two components, one of which improves the properties of the mixture or acts as a hardener. Forming the mixture immediately before leaving the head eliminates the mentioned problems related to the need to store the mixture formed before. An additional feature of the head is the use of a nozzle with a shielding gas supply connector, which accelerates the curing of the mixture extruded from the head. The review of the state of the art, made as part of the preparation of the patent application, which was filed with the Patent Office of the Republic of Poland, confirmed the originality of the idea and the lack of competitive solutions.

The versatility of the head allows for the delivery and mixing of various liquid building masses, as well as all liquid additives improving the properties of the mix. The research currently carried out in the Prototyping Laboratory of the Kielce University of Technology concerns building materials.
They are to confirm the applicability of the proposed head in the production of building components.

An important aspect in the construction industry is the ecofriendliness and naturalness of materials. An example may be a material called silicate, planned for use in this solution, containing no harmful admixtures, the production of which does not cause pollution or environmental degradation. In addition to the silicate mass, an enhancer in the form of lithium silicate will be added. The finished building material will be extruded in a carbon dioxide coating, which will ensure adequate curing of the mixture, and the executive device will create a building structure layer by layer. This solution can be particularly attractive in the case of production of nonstandard shapes, which must meet certain strength requirements, because it also saves time and costs (no need to build special forms).

- Head model. The head model is shown in figs. 7-9. The head has a housing 1 with a sleeve outline in which a stirrer 2 , sealed by a sealing ring 3 is rotatably mounted. Two ball bearings 4 are used for bearing the rotating agitator, separated by a spacer sleeve 5 , bearing its leading faces against the leading faces of the internal raceways of the bearings 4 . The upper part of the housing 1 is closed by a nut 8 . With the agitator 2 is connected - by means of a protrusion $6-$ a toothed pulley 7 , for transferring the drive. The head is equipped with a tube 9 , which is fed into its interior by a liquid building material, and in a nozzle 10 for feeding liquid additives. Inside the casing 1 of the head, at the level of the agitator screw, there is a replaceable teflon insert 11 , the rotation of which is blocked by the nozzles 10 . This insert allows better slip of the building material inside the head and at the same time protects the head and agitator against excessive wear. On the lower part of the housing 1, a nozzle 14 is mounted, by means of a screw 12 with a cap 13, covering the outlet of the housing 1 . The nozzle 14 is provided with a tube 15 for supplying a shielding gas which is supplied with the liquid building material.

With the use of a rotating agitator 2 in the chamber of the head housing 1 , the liquid building material mixes with liquid additives, affecting the properties of the mix. The finished building material is extruded from the casing 1 in the gas shield supplied to the nozzle 14 with the tube 15 . The agitator 2 is interchangeable and its shape is selected depending on the building material used.

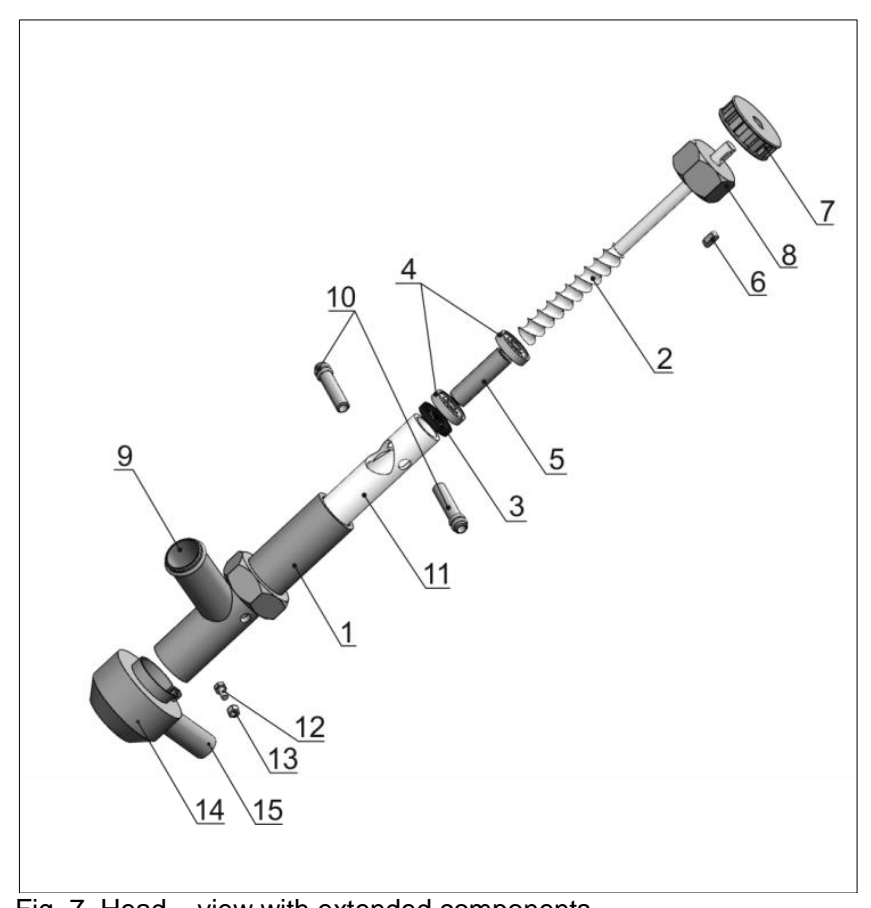

Fig. 7. Head - view with extended components 


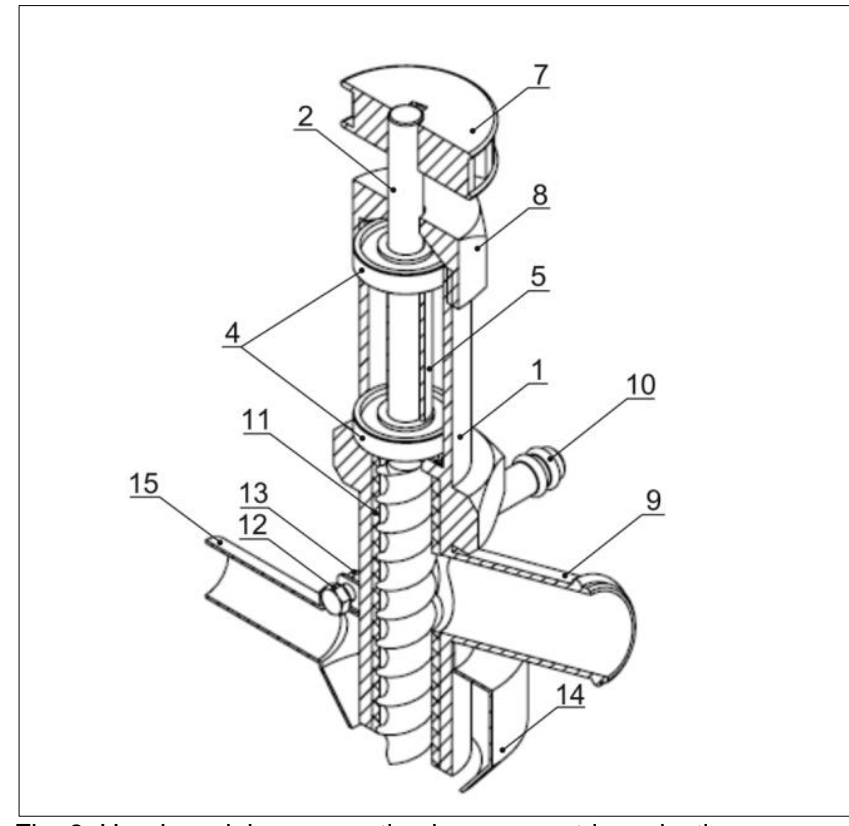

Fig. 8. Head - axial cross section in axonometric projection

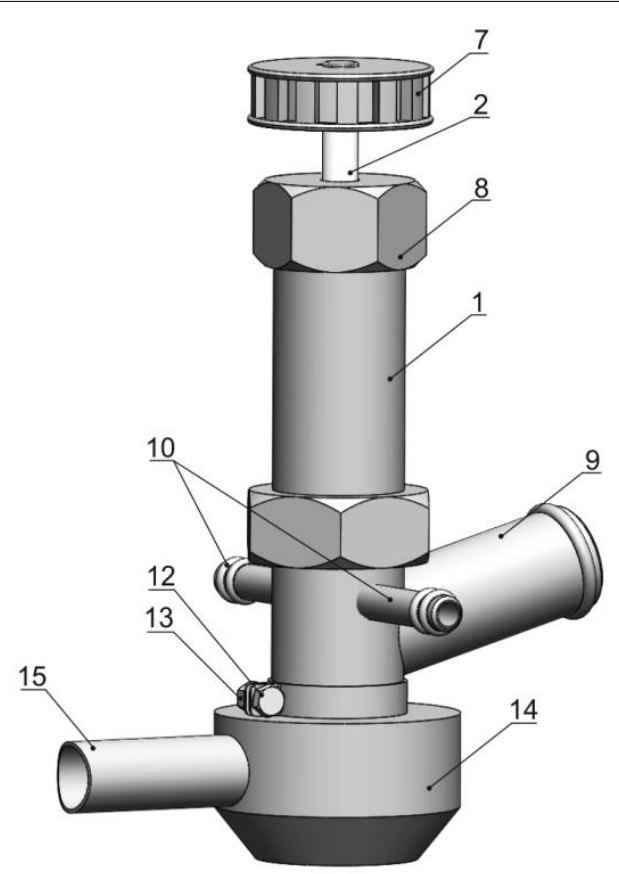

Fig. 9. Head - perspective view

The presented concept is the basis for making the prototype of the head and verification of the effectiveness of its operation and functionality in laboratory conditions.

\section{Planned experimental research}

The head prototype tests, being part of the commercialization process, will include four stages.

- Construction of the prototype. The prototype of the head according to the invention will be built in the Prototyping Laboratory of the Kielce University of Technology. The main elements (parts of the body, nozzle) will be made in incremental technologies using the ProJet 3510SD printer, which is the laboratory's equipment. The other parts of the head are elements available on the market (e.g. sleeves, screws, nuts). This will allow to quickly and cheaply build a prototype and allow modifications to ensure proper performance.
- Construction of a test stand. A research stand will be created, enabling prototype tests to be carried out, consisting of verification of the head's construction correctness, identification and selection of critical parameters to ensure the mapping of the target system in laboratory conditions. The modified elements of the existing station - 3D printers of their own construction - will be used to obtain the appropriate head movements. The following will be added: the drive system of the agitator located in the head and the delivery systems of mixed components. At the stage of laboratory tests, it is planned to administer a silicate mass and a liquid additive in the form of lithium silicate, which improves the compressive strength of the material. The delivery system will be adapted to these components. It will be the simplest to allow testing only on a laboratory scale. The installation will be supplemented with carbon dioxide, which accelerates the hardening process of the building material.

- Verification of the mixing system. The aim of this stage of the research will be to analyze the effectiveness of mixing a liquid building material with a liquid additive modifying the properties of the mixture. This requires the determination of critical geometric parameters - such as: dimensions and shapes of tubes supplying components, shape and length of the stirrer - and kinematic parameters, including the speed of the agitator, the flow of ingredients or the speed of material outflow from the head. In order to obtain the appropriate working parameters, it is possible to modify the dimensions of the head elements, which, however, involves the production of subsequent versions. It is relatively easy to implement thanks to the use of a $3 \mathrm{D}$ printer.

- Verification of the gas curing system. The last stage of the research will be the selection of parameters in the process of curing with carbon dioxide. The method of subsequent tests assisted by the analysis will be the selected pressure and the appropriate gas flow rate. It may also be necessary to change the shape and dimensions of the nozzle, which will involve the production of subsequent versions of the head

\section{Conclusions}

Modern construction requires the use of ecological materials with the appropriate technical parameters, as well as innovative technological solutions, streamlining the investment process and allowing, among others, for the implementation of non-standard, complex projects that could not be made using traditional methods. 3D printing technology faces these challenges. Projects implemented with its use show that the construction industry is increasingly appreciating the capabilities of 3D printers in the field of automation and robotization of labor-intensive construction works. It is hard to imagine, however, that this technology would completely replace the traditional methods of building. It is more likely that it will perform support functions, especially when creating elements distinguished by unusual geometry, which requires the use of building material with appropriate technical parameters, ensuring sufficient print quality.

The head presented in the article may be an attractive component of 3D printers used in the construction industry. Significant features of the head are:

- possibility of mixing various liquid building materials with additives affecting the properties of the mixture,

- printing in a gas shield.

In this way, tasks implemented in other solutions are combined through separate systems. The functional concept of the head was presented and its possible application was determined, which corresponds to the development of technology at the second level of the technological readiness level (TRL). Current research includes the construction of a 
prototype head together with the power supply system with building materials and experiments on a laboratory scale. This will allow the experimental verification of the concept and identification and selection of critical parameters to ensure the mapping of the target system in laboratory conditions and thus to locate the technology above the fourth level in the scale of technological readiness.

The results of the tests will be presented in the next part of the article.

Further activities should cover the commercialization process, so that the head, which is the subject of the patent application, has become a product available on the market.

This publication is financed from funds allocated for the implementation of a research project entitled "The prototype of the head for material feeding in incremental printers, equipped with a mixing system and a gas shield system" under the grant obtained from the project "Incubator of Innovation +", co-financed by the Ministry of Science and Higher Education.

\section{REFERENCES}

1. Gierulski W., Rębosz-Kurdek A., Stępień A., Szmidt A., Bajor T., Frydrych S., Furgał B., Kowalski S., Kwiatkowski J., Wojciechowski B. "Głowica do podawania materiału w drukarkach przyrostowych". Zgłoszenie wynalazku: P.423351, Warszawa 2017.

2. Siemiński P., Budzik G. „Techniki przyrostowe. Druk 3D. Drukarki 3D". Warszawa: Oficyna Wydawnicza Politechniki Warszawskiej, 2015.

3. http://centrumdruku3d.pl/historia-druku-3d-czesc-3-projekt-reprap-i-narodziny-niskobudzetowej-branzy-druku-3d-na-swiecie/ (dostęp: 15.05.2018 r.).

4. https://drukarki3d.pl/wdrozenia/ (dostep: 27.04.2018 r.)

5. https://www.digitaltrends.com/cool-tech/useful-3d-printed-household-items/ (dostęp: 29.04.2018 r.).

6. Fudali P., Miechowicz S., Kudasik T. „Koncepcja systemu podparcia wózka dla osób z niepełnosprawnością ruchową - prezentacja rozwiązania z zastosowaniem druku 3D". Mechanik. 5-6 (2017): s. 450-452.

7. Moon S.K., Tan Y.E., Hwang J., Yoon Y.J. "Application of 3D printing technology for designing light-weight unmanned aerial vehicle wing structures". International Journal of Precision Engineering and Manufacturing-Green Technology. 1, 3 (2014): s. 223-228.

8. Kumar L.J., Nair C.G.K. "Current Trends of Additive Manufacturing in the Aerospace Industry". W: Wimpenny D.I., Pandey P.M., Kumar L.J. (eds.), Advances in 3D Printing \& Additive Manufacturing Technologies. Springer, 2017.

9. https://3dprintingindustry.com/news/3d-printing-automotive-industry-2-82838/ (dostęp: 27.04.2018 r.).

10. Domański J., Skalski K., Grygoruk R., Mróz A. "Rapid prototyping in the intervertebral implant design process". Rapid Prototyping Journal. 21, 6 (2015): s. 735-746.

11. Murphy S.V., Atala A. "3D bioprinting of tissues and organs". Nature Biotechnology. 32 (2014): s. 773-785.

12. Major M., Minda I. „Zastosowanie druku przestrzennego w budownictwie". Budownictwo. 22 (2016): s. 238-247.

13. http://apis-cor.com/en/about/blog/features-and-perspectivesof-3d-printing (dostęp: 10.05.2018 r.)

14. https://3dprintingindustry.com/news/3d-printing-technique-currently-challenging-global-construction-industry-77432/ (dostęp:15.04.2018 r.)

15. Aroca R.V., Ventura C.E.H, De Mello I., Pazelli T.F.P.A.T. "Sequential additive manufacturing: automatic manipulation of $3 \mathrm{D}$ printed parts". Rapid Prototyping Journal. 23, 4 (2017): s. 653659.

16. Szmidt A., Rębosz-Kurdek A. „Sposoby doskonalenia druku 3D w technologii FDM/FFF”. Mechanik. 3 (2017): s. 258-261.

17. Adamczak S., Bochnia J., Kaczmarska B. "Estimating the uncertainty of tensile strength measurement for a photocured material produced by additive manufacturing". Metrology and Measurement Systems. 21, 3 (2014): s. 553-560.
18. Khoshnevis B., Yuan X., Zahiri B., Zhang J., Xia B. "Construction by Contour Crafting using Sulfur Concrete with Planetary Applications". Rapid Prototyping Journal. 22, 5 (2016): s. 848-856.

19. Khoshnevis B. "Automated construction by contour crafting related robotics and information technologies". Automation in Construction. 13, 1 (2004): s. 5-19.

20. http://spectra3d.com/3d-design/amazing-house-building-3dprinter/ (dostęp: 28.04.2018 r.).

21. http://www.3ders.org/articles/20160331-winsun-3d-prints-twogorgeous-concrete-chinese-courtyards-inspired-by-the-ancient-suzhou-gardens.html (dostęp: 28.04.2018 r.).

22. https://3dprint.com/207936/3d-printed-yhnova-house-done/ (dostęp: 10.05.2018 r.).
Translation of scientific articles, their computer composition and publishing them on the website www.mechanik.media.pl by original articles in Polish is a task financed from the funds of the Ministry of Science and Higher Education designated for dissemination of science.

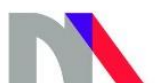

Ministry of Science and Higher Education

Republic of Poland 